\title{
BE BORN AS SUCCESSFUL MATHEMATICS OR LANGUAGE LEARNER: MYTHS, TRUE OR FALSE?
}

\section{Marek Sedlačík, Ivana Čechová, Lucie Doudová}

\begin{abstract}
Applied mathematics and English language belong among consequential subjects within the Faculty of Economics and Management curriculum. The authors focused on these two subjects and apart from their description they deal with entrance exam analysis for bachelor degree at the Faculty of Economics and Management, which is a part of the University of Defence. In an endeavour to widen the understanding referring to factors predicting academic achievement in tertiary education, the authors compare the entrance test results and try to find out whether there is an independent relationship between success in the English language test and success in the Learning Potential Test. Exploratory statistics and methods of non-parametric statistics for testing of the hypothesis regarding this relationship is described in the last part of this article.
\end{abstract}

\section{Key Words}

Applied mathematics, bachelor study programmes, English language, entrance exams analysis, multiple intelligences academic achievement
Czech University of Life Sciences Prague marek.sedlacik@unob.cz

\section{ARTICLE INFO}

Article type

Full research paper

doi: 10.7160/eriesj.2013.060303

Article history

Received: August 14, 2013

Received in revised form: September 13, 2012

Accepted: September 23, 2013

Available on-line: September 30, 2013 


\section{Introduction}

Today we live in a complex social and political world. More than ever before, we want to plan our own lives, we are expected to contribute actively to society, and must learn to live positively with cultural, ethnic and linguistic diversity. Education, in its broadest sense, is the key to learning and understanding how to meet the $21^{\text {st }}$ century challenges. The importance of education for Europe has been endorsed at the highest level in the last decades. "Europe can - and must show that it is possible both to achieve dynamic economic growth and to strengthen social cohesion. Emphasising that, people are Europe's main asset and should be the focal point of the Union's policies. Above all, education and training systems must adapt to the new realities of the $21^{\text {st }}$ century and that lifelong learning is an essential policy for the development of citizenship, social cohesion and employment" (European Council Presidency Conclusions). Student success has become a primary focus of today's educational institutions and is an area of national concern.

Education and training has been crucial for successful career and life, for growth and jobs and they have been a key element for its follow-up with the 2020 perspective. In accordance with Education and Training 2010 work programme "creating a well-functioning knowledge triangle of education, research and innovation and helping all citizens to be better skilled are crucial for growth and jobs, as well as for equity and social inclusion". The European Framework for Key Competences for Lifelong Learning identifies and defines eight key competences necessary for personal fulfilment, active citizenship, social inclusion and employability in a knowledge society:

- communication in the mother tongue;

- communication in foreign languages;
- mathematical competence and basic competences in science and technology;

- digital competence;

- learning to learn;

- social and civic competences;

- sense of initiative and entrepreneurship;

- cultural awareness and expression (Education and Training 2010 work programme; Crick, R. D., 2008).

European Union in its endeavour to apply the above mentioned competences into the member states education policies as well as to improve education and training systems set the following strategic objectives:

- improving the quality and effectiveness of education and the measurement of progress through agreed instruments;

- facilitating the access of all to education and training systems;

- opening-up education and training systems to the wider world.

However, the successful mastery of academic content, once viewed entirely as the learners' responsibility, is now considered a shared responsibility between three major players: the student, the teacher, and the educational institution.

Faculty of Economics and Management teachers are fully aware of the European education policy and they strive for applying it in their teaching practice. 


\section{Mathematic and linguistic intelligences}

However, the authors, teachers of applied mathematics and English language, quite often face the widespread prejudice: "people are either born good at mathematics or language". Is it true or myth? Is it possible to be good at both subjects? And how to achieve it?

Generally said, people have multiple intelligences but most people excel in only few areas because it is what they develop, for example, most artists develop and practice their skills in the arts more, so they tend to neglect the mathematics and science. Mathematics and languages are controlled by different sides of the brain: aptitude in mathematics is controlled by the left brain, while aptitude in languages is controlled by the right and people are either more of the left-brainer than the right-brainer. Some people balance their aptitudes, but most people don't.

According to Howard Gardner, a psychologist and professor of neuroscience from Harvard University, human beings have eight different kinds of intelligence that reflect different ways of interacting with the world:

- Linguistic intelligence (word smart)

- Logical/Mathematical intelligence (number/reasoning smart)

- Spatial intelligence (picture smart)

- Musical Rhythmic intelligence (music smart)

- Bodily/Kinaesthetic intelligence (body smart)

- Intrapersonal intelligence (self-smart)

- Interpersonal intelligence (people smart)

- Naturalist intelligence (nature smart).
Gardner's theory has emerged from recent cognitive research and documents the extent to which students possess different kinds of minds and therefore learn, remember, perform, and understand in different ways (Gardner, 1990). According to this theory, "we are all able to know the world through language, logical-mathematical analysis, spatial representation, musical thinking, and the use of the body to solve problems or to make things, an understanding of other individuals, and an understanding of ourselves" (Gardner, 1990). This theory has been confirmed in the Lazear research as well (Lazaer, 2003).

Where individuals differ is in the strength of these intelligences - the so-called profile of intelligences - and in the ways in which such intelligences are invoked and combined to carry out different tasks, solve diverse problems, and progress in various domains. "Each person has a unique combination, or profile. Although we each have all eight intelligences, no two individuals have them in the same exact configuration" (Gardner, 1990).

In his later work Gardner states: "Much work needs to be done on the question of how the intelligences can best be mobilized to achieve specific pedagogical goals" (Gardner, 2003). It is complicated to grasp multiple-intelligences theory and implement its implications effectively. However, those teachers who thoughtfully use this theory to support their wider educational goals find it a worthy partner in their subject improvement.

The objective of this paper is to assess and interpret relations and dependencies among variables characterizing mathematic and linguistic intelligences. In particular, the paper aims to compare relationship between success in the English language test and 
in the Learning Potential Test and to find out what differences or similarities there are between English language and Applied mathematics marks.

To fulfil the above listed aims, instruments of descriptive statistics and methods of non-parametric statistics have been applied. All the calculations have been performed using the Application STAT1 (Neubauer, Sedlačík and Kř́iž, 2012) and the STATISTICA 11 software.

\section{Materials and Methods}

The University of Defence (UoD) ensures education both of Czech Army specialists and civil students within accredited bachelor, master and doctoral study programmes. All these programmes have two basic forms of study - full-time and combined, which are legalized by the Act no. 111/1998 Coll., on universities $\S 44$., The UoD strives to accommodate the interests of military and civilian study candidates, who wish to complement their existing education in accordance with the rising demands on qualifications and respond to the change of professional orientation or the needs of requalification. By this, the UoD is reflecting European and worldwide life-long learning trends. Students of both forms have to fulfil the same requirements, although the students of the combined form have to join their study with a regular job and everyday duties.

Faculty of Economics and Management (FEM) provides university education in - Bachelor's degree programme, Followup Master's degree programme, and PhD degree programme. The bachelor's degree programme qualifies students to cope with the managerial processes on the knowledge platform specifically in branches such as management, economics, law, mathematics, statistics and informatics. In the next part of the article the authors will concentrate on only Applied Mathematics and English language, core subjects of entrance exam at the Faculty of Economics and Management.

\section{Applied Mathematics}

As mentioned in the above paragraph, we will focus on teaching such FEM subjects which we can classify into the group of Applied Mathematics. Specifically, it refers to curricular subjects taught within the bachelor study programme, i.e. Mathematics, Statistics and Basics of Operational Research. We will also mention chosen follow-up subjects which are taught in the master study programme, possibly in the doctoral study programme. This part of education represents the essential tool which forms FEM graduates especially while clarifying and solving real phenomena and problems, modelling decisionmaking situations, decision-making under uncertainty, risk preventing and analysing for troops, citizens and property protection, solving the economics of national defence issues, etc. The subject Mathematics is taught in the $1^{\text {st }}$ and $2^{\text {nd }}$ terms and assumes the knowledge of secondary schools Mathematics. The subject provides theoretical basis for a number of special and profile subjects which are taught at FEM. They are followed by subjects taught both by the Department of Econometrics itself, and by specialist departments. This subject includes following topics:

- Linear Algebra

- Elementary Functions

- Differential Calculus of Functions of One Variable

- Integral Calculus of Functions of One Variable

- Differential and Difference Equations

- Differential Calculus of Functions of More Variables 
The subject Statistics is taught in the $3^{\text {rd }}$ term and it follows the subject Mathematics. It contains the explanation of basic terms from probability, mathematical statistics, and the basic concepts of its theory and statistical methods of parameter estimation and hypothesis testing. The teaching is supported by the computer data processing, software STAT1 and R (Neubauer, 2012). The aim of the subject is to understand the stochastic way of thinking while evaluating data from the practice. The content of the subject is following:

- Probability

- Descriptive Statistics

- Random Variable

- Inductive Statistics

The following subject Basics of Operational Research is taught in the $4^{\text {th }}$ term and it follows subjects Mathematics and Statistics. The subject deals with basic principles and methodology of the mathematical modelling of decision-making situations. Students learn how to solve standard tasks from linear programming, i.e. the operations planning task, nutrition problem, distributive problem, transport task, assignment problem. The subject includes following topics:

- System Theory

- Linear Programming

- Allocation Problems

In further study the above mentioned three subjects are followed by subjects like Logic Basics, Economic-Mathematics Methods, Statistics II, Risks Rating and their Modelling, Applied Mathematics and Statistics, etc.
It is necessary to remark that currently there is in progress the preparation for accreditation acquiring of the continuous master study programme which is in accordance with the requirements of the Army of the CR General Staff / the Ministry of Defence of the CR (GS/MO), educational field Security Branches of the National Qualifications Framework. It is obvious that in connection with the planned change the above described structure of subjects included in the area of Applied Mathematics will be significantly modified; the basic subjects of Applied Mathematics will be followed by subjects more oriented into the sphere of security, risk rating etc.

Educators quite often have to answer a question if students can be good both at mathematics and languages. The term 'good' is a relative concept. If a good learner could be defined, the opposite end of spectrum, a bad language learner, should also exist. However, how could a teacher or a test define the specific point where 'good' becomes 'bad'? The answer to this question would be highly subjective and would vary significantly depending on numerous factors such as class dynamics, objectives, the scale and duration of the study, etc. (Slimani, 2001). There have been a number of attempts to specify the qualities of the 'good learner', based on studies carried out by Rubin (1975), Naiman et al (1978). These studies found that "...good learners take advantage of potentially useful learning situations, and if necessary create them. They develop learning techniques and strategies appropriate to their individual needs."

A recent study conducted by researchers from Johns Hopkins University in Baltimore confirms that there are people who are born for good or just not good at math (Stanley, Keating \& Fox, 1974). One's mathematical ability according to the results of the study is determined by innate factors. Congenital factor is referred to as i 'number sense' or sensitivity to the numbers 
(Libertus, 2011). "We believe that 'number sense' is universal, whereas math ability has been thought to be highly dependent on culture and language, and takes many years to learn," Melissa Libertus, lead author of the study, said. Researchers discovered that number sense was innate by testing 200 children on several tasks measuring number sense, mathematical ability and verbal ability.

Learning a second language is usually difficult and often when we speak it we cannot disguise our origin or accent. Some students claim that they love to learn and improve, but they have just got "no talent" for languages. However, there is no evidence that there is a critical period for academic skills such as learning a foreign language. The reason is the remarkable plasticity of the brain throughout life. There are "sensitive periods" for certain aspects of language learning - "windows of opportunity" within which people can acquire certain ability most easily and efficiently. But there's no reason that adults can't learn a new language and acquire an almost native accent (Diaz at al, 2012).

However, each student is responsible for his/her own learning. Students' motivation, determination, and discipline makes the greatest difference in how effectively they learn, no matter how well developed their intellectual abilities are. The learning behaviour also makes the greatest difference in students' job, personal life, and as a responsible citizen of society long after university studies.

\section{English language}

The UoD as well as the Faculty of Economics and Management emphasize studying foreign languages because the Czech Army belongs to the NATO structures. Language training is a very important part of the curriculum. English is undoubtedly a priority as it is a mandatory subject for all students at the University. However, all students have to study two foreign languages. In addition to the obligatory English, they can choose German, French or Russian as the second language.

Languageeducationat theFaculty ofEconomicsand Management of the UoD respects the standard of NATO STANAG 6001 and is managed according to the Common European Framework of References, which sets individual competences, especially the communicative one. Communicative competence assumes knowledge of the socio-cultural environment of the particular country where the language is spoken as the target competence of language education. Knowledge of foreign languages helps reduce language barriers and is essential for increasing individuals' mobility both in their personal and professional lives.

Consequently, the basic teaching approach is the communicative method which comprises the whole spectrum of activating methods, the aim of which is to improve students' motivation and creativity. The two-way process of language education assumes two participants and consists of two communicative processes. The speaker (writer) produces his/her speech and transfers information. The listener (reader) receives the information and reacts to it. In other words, every student of foreign languages needs a whole range of skills and abilities, 
e. g. writing letters and emails, reading books, listening to the radio, speaking on the phone, which supposes four basic language skills:

- Listening comprehension

- Speaking

- Reading comprehension

- Writing

Bachelor degree students study General English in the first semester and then they follow by special topics, divided to the following modules

Military modules, with topics such as:

- Military Ranks; Daily Routines and Responsibilities; Uniform and Equipment; Branches of the Army; Combat Vehicles; Terrain;

- Armed Forces; Military Service; Army of the Czech Republic; Land Forces; Air Force; Current Deployments; Peace Support Operations; Women in the Military;

- International Organizations; European Union; NATO; United Nations; Humanitarian Assistance; Problems of Today; Security Risks and Threats;

Economic module:

- Introduction to the Economic System; Production; Business Cycle; Types of Business Organizations; Marketing the Product; Starting a Business; International Trade; Transport and Communication; People and Work;

The last semester of bachelor's degree is focused on STANAG topics, such as:

- Environment; Crime, Gun Possession; Discrimination, Xenophobia, Racism; Addictions, Bad Habits; Terrorism;
Students' language competence is examined not only at the compulsory tertiary exam which focuses on English for General Academic Purposes, and partly on English for Specific Academic Purposes, but also at standardized NATO language exam STANAG 6001. The students are expected to pass SLP 2 in English, which corresponds to B1 level according to the Common European Reference Framework.

The usage of information technologies is one of the possibilities how to teach more effectively and attractively. Teachers of the Language Training Centre have used in their work different electronic tools (LMS MOODLE, LMS Barborka, web-based conferencing, emails $C D$, etc.) as well as findings from the latest research to make teaching and learning languages more efficient.

\section{Entrance exams at the Faculty of Economics and Management}

Applicants for the military full-time study programme take in their entrance exam these following tests:

- Learning Potential Test - written test

- English language - written test

- Physical fitness - practical test

Applicants for the military part-time study programme and civilian (both full time and part time) take Learning Potential Test only.

The Learning Potential Test (LPT) is divided into three parts; each part always contains ten questions. 
The first part deals with numeric thoughts and logic, the second part focuses on spatial imagination and abstract thinking, and the last part concentrates on basic mathematical skills. Learning Potential Test result is assessed between 0 to 60 points; a pass mark for this test is 30 .

The English language test (ELT) examines reading comprehension, vocabulary and grammar. The minimal entrance level should be at least A2 according to the Common European Framework of Reference for Languages, or SLP 1 (Standardized Language Profile) according to NATO STANAG 6001. The English language test is assessed between 0 to 50 points; a pass mark for this test is 25 .

With regard to this contribution the authors will not describe practical fitness test in detail. Detailed information regarding the entrance exam is available at the University of Defence web site.

\section{Hypotheses and Methods of their Verification}

In order to identify relations and dependencies among determinants, values of which have been gathered in relation to international armaments cooperation, the following hypotheses have been formulated. These hypotheses are focused on the key cost considerations of international armaments cooperation:

- Are there any differences between English Language Test (ELT) and Learning Potential Test (LPT) tests at military students?

- Are there any differences between ELT and LPT tests at civilian students?

- Do the ELT marks and LPT marks correlate?

- Is there any relationship between ELT and LPT?
The hypotheses have been verified using data resulting from the entrance exams at the Faculty of Economics and Management. To compare the findings on the whole, explorative analyses methods were used (Neubauer, Sedlačík and Kříž, 2012). Next analyses was dealing with a group of the military full time study programme applicants and the normality was both tested assessed to measure the association of variables that has been characterized by Pearson's correlation coefficient (Andel, 2003). Finally, the Pearson test of independence in the contingency table (Rauchová and Houška 2013) and a Fisher's exacts test have been used and p-value were calculated. Fore detailed description of the above mentioned statistical methods used to test hypothesis within this paper see Agresti (2002), Johnson and Wichern, (2007).

\section{Results and Discussion}

Exploratory statistics was the first step of our research. The authors used data gathered from 2011, which means academic year 2011/2012. To illustrate a basic reference to frequency distribution, a histogram from pass marks received in both the LPT and the ELT were created (Figure 1).

Altogether, 796 applicants were analysed; out of this number 345 were military full time study programme applicants, 54 were military part time study programme applicants (for these applicants the English language test was not required), and 397 were applicants for the civilian study programme. 

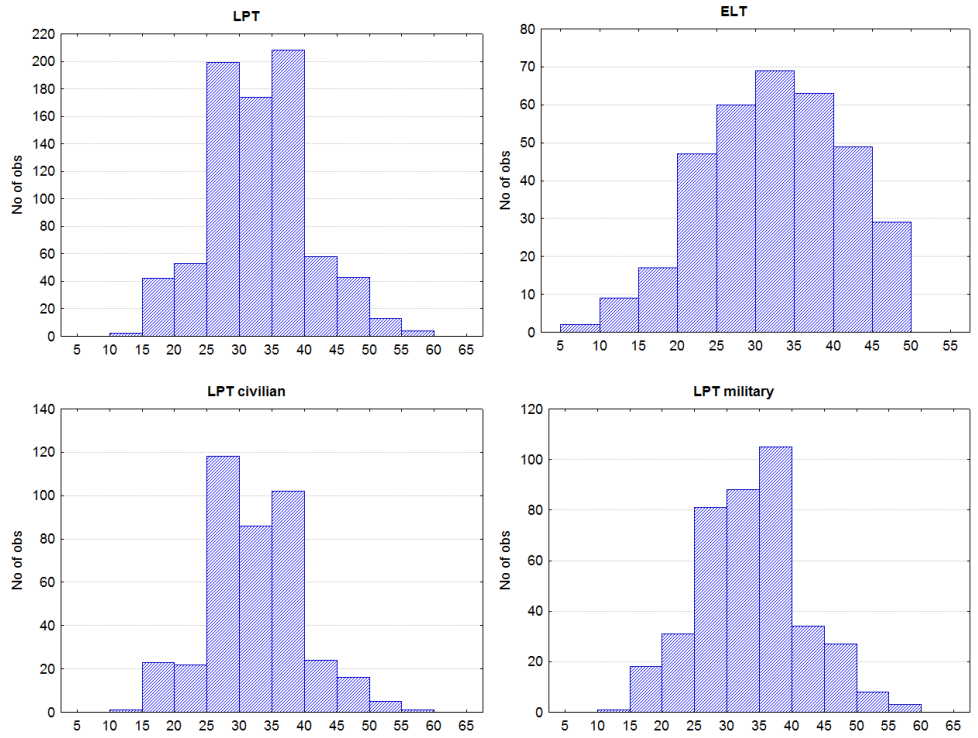

Figure 1: Histograms of the LPT and the ELT

In the ELT $18.26 \%$ of applicants failed and $81.74 \%$ of applicants passed. In the LPT $27.11 \%$ failed and $72.89 \%$ passed.

\begin{tabular}{|l|c|c|}
\hline & LPT & ELT \\
\hline Valid N & 796 & 345 \\
\hline Mean & 33.51 & 32.94 \\
\hline Median & 34 & 33 \\
\hline Mode & 32 & 39 \\
\hline Minimum & 12 & 10 \\
\hline Maximum & 56 & 50 \\
\hline Lower Quartile & 28 & 26 \\
\hline Upper Quartile & 38 & 39 \\
\hline Std.Dev. & 7.59 & 8.85 \\
\hline
\end{tabular}

Table 1: Descriptive characteristics
If we look at the data characteristics in detail, it is obvious that basic indicators of position (mean, median, mode See Table 1) all exceed the "passing grade" assigned to both tests, the LPT and in particular the ELT. It is possible to compare these results with those in the figure below (Figure 2), which demonstrates that in the LPT the military applicants were more successful in comparison with civilian students; $75 \%$ of military applicants exceed a score of 30 points. A similar result was found in the ELT as well.

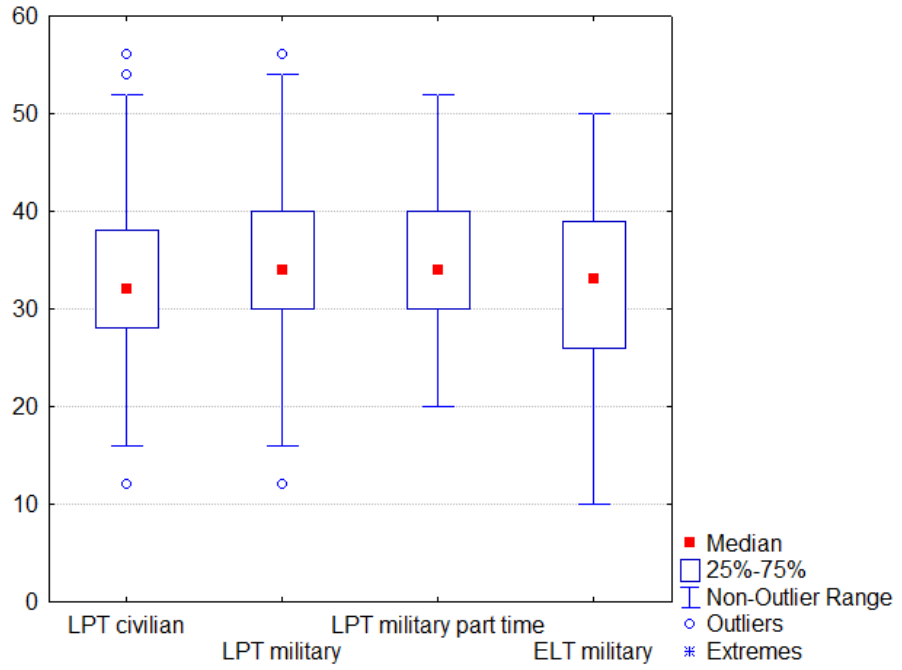

Figure 2: Box Plot of particular groups of applicants in the LPT and the ELT

Figure 2 shows that in a group of civilian and military applicants of the full time study programmes outliers occur. 
In the next part, the hypothesis regarding an independent relationship between success in the English language test and success in the LPT was tested. It is essential to add that this research was only possible for those students who took both tests - the LPT and the ELT - which were a group of applicants for the military full time study programme. The overall results are stated in the below-mentioned Figure 3.

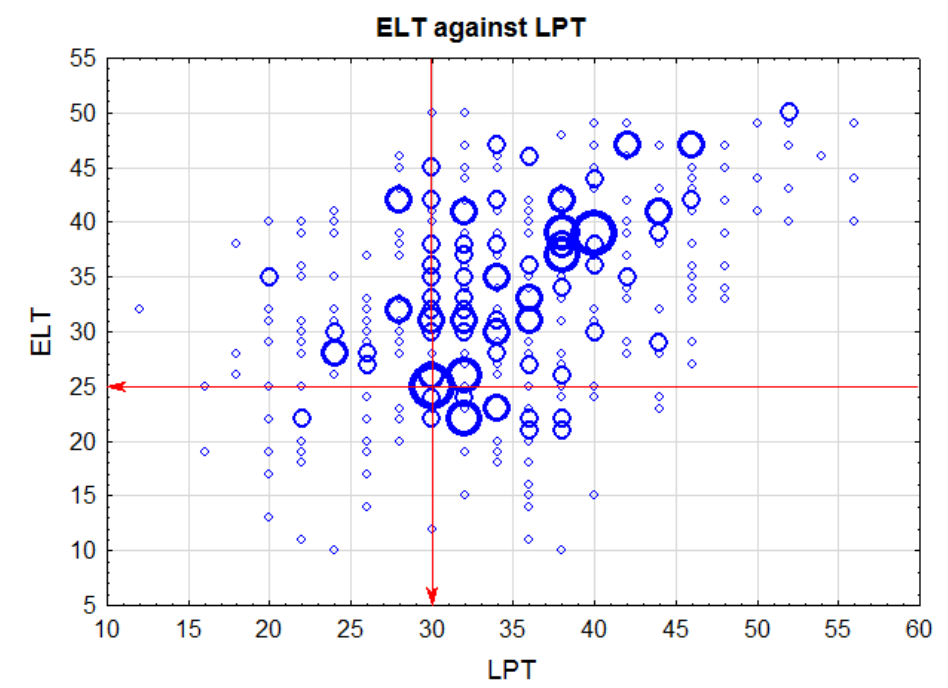

Figure 3: Scatterplot of ELT against LPT

Two-dimensional classification of attained marks frequency in both ELT and LPT is demonstrated by bubbles. Both tests pass marks are drawn colourfully. In these sectors it is possible to perceive that minimum level in both tests was attained by $64 \%$ of students (see table 2).
In accordance with hypotheses, the normality of above given data was tested by standard statistical methods (see Johnson and Wichern, 2007; Neubauer, Sedlačík and Kř́iž, 2012). At the 5 $\%$ level of significance it is possible to state that attained marks in both tests come from normal, two-dimensional distribution.

To describe the results of the survey and to verify relations among individual categories of applicants, besides using their basic characteristics the Pearson's correlation coefficient $R$ has been calculated and tested (Andel, 2003) in order to examine relation between the individual categories of variables. The variable ELT significantly at the $5 \%$ level of significance and positively linearly correlates with variable LPT, $R=0.41, p$-value $<0.05$.

To verify relationship between success in the ELT and success in the LPT it is possible to use (Johnson and Wichern, 2007; Andel, 2003) the Pearson $\chi^{2}$ test of independence in the contingency chart (see Table 2) and a Fisher's exacts test. The calculations are completed at the level of significance of $5 \%$.

\begin{tabular}{|c|c|c|c|c|}
\hline \multicolumn{2}{|c|}{} & \multicolumn{2}{c|}{ ELT } & \multirow{2}{*}{ Total } \\
\cline { 3 - 4 } & Failed & Passed & \\
\hline \multirow{2}{*}{} & Failed & 21 & 60 & 81 \\
\cline { 2 - 4 } & Passed & 42 & 222 & 264 \\
\hline \multicolumn{2}{|c|}{ Total } & 63 & 282 & 345 \\
\hline
\end{tabular}

Table 2: $2 \times 2$ chart of the independence test

For the above mentioned outcomes, the following $p$-values were calculated: for the Pearson $\chi 2$ test $p=0.04123$ and for Fisher's test $p=0.04874$. Both $p$-values are less than a chosen level of significance of $5 \%$; therefore we can reject at the level 
of significance of $5 \%$ the hypothesis regarding an independent relationship between success in the ELT and success in the LPT. Table 2 shows that a group of applicants successful in both the LPT and the ELT predominate noticeably.

\section{Conclusion}

The above mentioned results prove the link between the Learning Potential Test and the English language test. If an applicant is good at English, he or she is good at the Learning Potential Test too. It is obvious that being good at mathematics does not necessarily mean being bad at languages.

The explanation can be very simple. Some people can have a greater aptitude for complex, or not-so-complex, mathematical operations than others; on the other hand some people can pick up languages so easily that we say they have a special gift, a socalled "ear for languages".

There is still a question of who has natural ability and who doesn't may get to the heart of the divide. If a student approaches a subject thinking that he or she is not very good at it, he or she may not work as hard to master it. The authors think that approaching mathematics or a foreign language with the sense that it is hard may affect students' ability to learn it. Teachers say that with enough hard work, motivation and practice, those who may not think they are good at mathematics or foreign language may end up being good students.

The further authors' endeavour is to observe the students study results during their studies and to find out how successful they are in the core subjects. Besides Applied Mathematics and English language the authors have already gathered the students' marks from Economics, Management, Law and some military subjects.

\section{References}

Agresti, A. (2002) Categorical Data Analysis, John Wiley \& Sons. Anděl, J. (2003) Statisticke metody, Praha: Matfyzpress.

Crick, R. D. (2008) Key Competencies for Education in a European Context: narratives of accountability or care. [online], Available: http://www.wwwords.co.uk/pdf/freetoview.asp?j=eerj\&vol=7 \&issue=3\&year=2008\&article=5_Crick_EERJ_7_3_web [2 May 2013].

Díaz, B., Mitterer, H., Broersma, M., \& Sebastian-Galles, N. (2012). 'Individual differences in late bilinguals' L2 phonological processes: From acoustic-phonetic analysis to lexical access', Learning and Individual Differences, vol. 22, no. 6, pp. 680-689. European Council Presidency Conclusions (2010) [online], Available: http://www.consilium.europa.eu/uedocs/cms_data/ docs/pressdata/en/ec/108622.pdf [2 Apr 2013].

Education and Training 2010 work programme (2010) [online], Available: http://ec.europa.eu/education/lifelong-learningpolicy/policy-framework_en.htm [2 Apr 2013].

Gardner, H. (1999) Intelligence reframed: Multiple Intelligences for the 21st century. New York, USA: Basic Books.

Gardner, H. Multiple Intelligences After Twenty Years. (2003) [online], Available: http://www.consorzionettuno.it/ materiali/B/697/773/16/Testi/Gardner/Gardner_multiple_ intelligent.pdf [24 May 2013].

Johnson, R. A., Wichern, D. W. (2007), Applied Multivariate Statistical Analysis, Pearson Prentice Hall.

Lazear, D. Eight Ways of Teaching: The Artistry of Teaching with Multiple Intelligences. Glenview: SkyLight Professional Development, 1900 East Lake Avenue. 2003. ISBN-1-57517-852-4. 
Libertus, M. E. Halberda J. (2011) 'Preschool acuity of the approximate number system correlates with school math ability', Developmental Science, vol. 14, no. 6, pp. 1292-1300.

Neubauer, J., Sedlačík, M. and Kříž, O. (2012) Zaklady statistiky - Aplikace v technickych a ekonomických oborech, Praha: Grada Publishing.

Neubauer, J., Sedlačík, M. and Kř́žž, O. (2012) Aplikace STAT1, [online], Available: http: //k101.unob.cz/stat1/ [9 Jul 2013].

Rauchová, T. and Houška, M. (2013) ‘Efficiency of Knowledge Transfer Through Knowledge Texts: Statistical Analysis', Journal on Efficiency and Responsibility in Education and Science, vol. 6, no. 1, pp. 46-60, [on-line] , Available: http://www.eriesjournal. com/_papers/article_207.pdf [9 Jul 2013].

Slimani, A. (2001) Evaluation of Classroom Interaction. Candlin and Mercer (2001). 287-305.

Stanley, J.C., Keating, D.P., \& Fox. L.H. (1974) Mathematical talent: Discovery, description, and development. Baltimore, Maryland: Johns Hopkins University Press.

Stern, H. (1983) Fundamental Concepts of Language Teaching. Oxford: OUP. 